\title{
CLINICAL STUDY OF GALLSTONE DISEASE AND TREATMENT OPTIONS
}

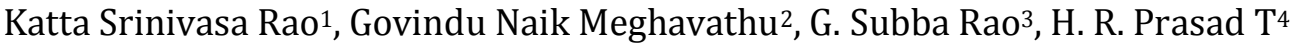

\section{HOW TO CITE THIS ARTICLE:}

Katta Srinivasa Rao, Govindu Naik Meghavathu, G. Subba Rao, H. R. Prasad T. "Clinical Study of Gallstone Disease and Treatment Options". Journal of Evolution of Medical and Dental Sciences 2015; Vol. 4, Issue79, October01; Page: 13841-13848, DOI:10.14260/jemds/2015/1972

ABSTRACT: The prevalence of gallbladder stones varies widely in different parts of the world. In India it is estimated to be around 4\% whereas in western world it is $10 \% .{ }^{1}$ In India, it is seven times more common in the north than in the south and it varies with Age, sex and ethnic group. ${ }^{2}$ Because of increased incidence of gall stones and its variable presentations in India as well as in the west, there is a great need for a study which can provide the information regarding the prevalence of the disease, various clinical presentations and management, outcomes of the cholelithiasis. OBJECTIVES: 1 . To study the age and sex distribution in patients presenting with cholelithiasis 2 . To study the various modes of presentation of cholelithiasis. 3. To study the type of gall stones 4. To study the various treatment modalities available and its outcome. MATERIALS AND METHODS: This study includes a total of 126 cases that were studied prospectively over a period of two years that were treated on inpatients basis from November 2012 to October 2014. All the cases were admitted, examined, investigated and operated. Inclusion criteria: All cases of gall stones, inflamed gall bladder with stones, Gall bladder mass with stones. Exclusion criteria: Bile duct stones, Cirrhosis and pregnant women. RESULTS: Highest incidence of Gall stone is in the fifth decade more common in females, commonest is pain right upper quadrant, sign is tender right hypocondrium. Ultrasound is a useful diagnostic tool. Lap cholecystectomy is the gold standard surgery, the conversion rate was $10 \%$. Wound infection was the most common post-operative complication. Lap Cholecystectomy reduces duration of hospital stay. Commonest stone is mixed stone. CONCLUSION: The incidence of gall stones was highest in $5^{\text {th }}$ decade and in females. Laparoscopic cholecystectomy reduced the duration of hospital stay, pain and disability and the conversion rate was $10 \%$. The commonest stone was mixed stone.

KEYWORDS: Gall stones; Open Cholecystectomy; Laparoscopic Cholecystectomy.

INTRODUCTION: The malady of gallstones dates back to Egyptian dynasty and archeological reports suggest that young woman had gall stones 2000 years back. ${ }^{3}$ Gall stones are a major cause of morbidity throughout the world and new gall stones form in about $3 \%$ of population over the age of 40 years, ${ }^{4}$ Gallstones in patients without biliary symptoms are commonly diagnosed incidentally on ultrasonography, CT scan, abdominal radiography, or at laparotomy. Approximately $3 \%$ of asymptomatic individuals become symptomatic per year (i.e., develop biliary colic).Once symptomatic, patients tend to have recurring bouts of biliary colic. Complicated gallstone disease develops in 3to5\% of symptomatic patients per year. Over a 20-year period; about two thirds of asymptomatic patients with gallstones remain symptom free. ${ }^{5}$

Diagnosis of gall stones is by proper history and physical examination and combining it with appropriate investigation. Changing incidence in India is mainly attributed to westernization and availability of investigation like ultrasound to urban as well as rural area and also because of increase affordability due to change in the socio-economic structure and the cost of investigations.

Ultrasound has emerged as the preferred test for the evaluation of patients with suspected cholelithisis or cholecystitis. ${ }^{6}$ Ultrasound is the simplest and most reliable method for diagnosis of gall 


\section{ORIGINAL ARTICLE}

stones. ${ }^{7}$ traditionally open cholecystectomy has been the gold standard for all patients with symptomatic gall stones. The safety of traditional cholecystectomy is due to the availability of welltrained surgeons with an appreciation of normal biliary anatomy and its variations. ${ }^{7,8}$ Innovations and new endeavors have resulted in the evolution of new surgical approach called minimally invasive surgery. ${ }^{9}$ which has revolutionized gall bladder surgery. Gall stones are composed of cholesterol, bilirubin and calcium salts with smaller amounts of protein and other material.10

Because of increased incidence of gall stones and its variable presentations in India as well as in the west, there is a great need for a study which can provide the information regarding the prevalence of the disease, various clinical presentations and management, outcomes of the cholelithiasis.

AIMS AND OBJECTIVES: 1. To study the age and sex distribution in patients presenting with cholelithiasis2. To study the various modes of presentation of cholelithiasis. 3. To study the type of gall stones4. To study the various treatment modalities available and its outcome.

MATERIALS AND METHODS: This study includes a total of 126 cases that were studied prospectively over a period of two years that were treated on inpatients basis from November 2012 to October 2014.All the cases were admitted, examined, investigated and operated.

RESULTS: This study includes a total of 126 cases that were studied prospectively over a period of two years that were treated on inpatients basis from November 2012 to October 2014.

\section{AGE INCIDENCE}

\begin{tabular}{|c|c|c|}
\hline Age group (years) & Number of cases & Percentage \\
\hline $11-20$ & 3 & 2 \\
\hline $21-30$ & 18 & 14 \\
\hline $31-40$ & 26 & 21 \\
\hline $41-50$ & 39 & 31 \\
\hline $51-60$ & 31 & 25 \\
\hline$>60$ & 9 & 7 \\
\hline \multicolumn{2}{|c|}{ Table 1: Age-wise incidence } \\
\hline
\end{tabular}

There was an increased incidence of cholelithiasis in the $5^{\text {th }}$ and $6^{\text {th }}$ decade with the peak incidence in $5^{\text {th }}$ decade. In this study the youngest patient was 19 years old and the oldest patient was 80 years old.

Distribution of Cases by Sex: In the present study 86 patients were female and 40 patients were male. The present study shows gallstones diseases were a common problem in female population. The female to male ratio is approximately $2: 1$. 


\section{ORIGINAL ARTICLE}

\section{ULTRASOUND:}

\begin{tabular}{|c|c|c|}
\hline Ultrasound findings & Number of cases & Percentage \\
\hline Stones in gallbladder & 126 & 100 \\
\hline Multiple stones & 101 & 80 \\
\hline Thickeningof gallbladder & 80 & 63 \\
\hline Solitary stone & 25 & 20 \\
\hline Mass & 5 & 4 \\
\hline
\end{tabular}

Ultrasound scanning of the abdomen was done in all patients. 126 patients had stones in gallbladder with 101 patients having multiple stones 25 patients having single stone with thickening of Gall bladder in 80 patients.

\begin{tabular}{|c|c|c|}
\hline Type of operation & Number of cases & Percentage \\
\hline Laparoscopic cholecystectomy & 86 & 68 \\
\hline Open cholecystectomy & 30 & 24 \\
\hline $\begin{array}{c}\text { Laparoscopic to open } \\
\text { cholecystectomy }\end{array}$ & 10 & 8 \\
\hline
\end{tabular}

Table 3: Type of operation

In the present study, 86 patients underwent laparoscopic cholecystectomy and 30 patients underwent open cholecystectomy and 10 patients from Laparoscopic to open cholecystectomy.

\begin{tabular}{|c|c|}
\hline Type of operation & Mean Operating room time \\
\hline Laparoscopic cholecystectomy & $55 \mathrm{~min}$ \\
\hline Open cholecystectomy & $110 \mathrm{~min}$ \\
\hline \multicolumn{2}{|c|}{ Table 4: Operating room time } \\
\hline
\end{tabular}

The mean operating room time for open cholecystectomy was $110 \mathrm{~min}$ and lap cholecystectomy was 55 min.

\begin{tabular}{|c|c|c|c|}
\hline $\begin{array}{c}\text { Postoperative } \\
\text { complications }\end{array}$ & $\begin{array}{c}\text { Laparoscopic } \\
\text { cholecystectomy }\end{array}$ & $\begin{array}{c}\text { Open } \\
\text { cholecystectomy }\end{array}$ & Total \\
\hline Wound infection & 0 & 12 & 12 \\
\hline Hemorrhage & 0 & 0 & 0 \\
\hline Retain stone & 0 & 0 & 0 \\
\hline Bile leak & 1 & 0 & 1 \\
\hline Prolong ileus & 2 & 6 & 8 \\
\hline \multicolumn{2}{|r|}{ Table 5: Postoperative complications } \\
\end{tabular}

In the present study 12 patients had wound infection. 1 patient had postoperative bile leak which was managed conservatively and patient recovered. 


\section{ORIGINAL ARTICLE}

\begin{tabular}{|c|c|}
\hline Operation & Mean Duration of stay \\
\hline Open cholecystectomy & 8 \\
\hline Laparoscopic Cholecystectomy & 3 \\
\hline \multicolumn{2}{|c|}{ Table 6: Duration of hospital stay } \\
\hline
\end{tabular}

Mean Duration of hospital stay: Postoperative length of stay was 8 days for open cholecystectomy and 3 days for laparoscopic cholecystectomy.

\begin{tabular}{|c|c|c|}
\hline Type of stone & Number of cases & Percentage \\
\hline Mixed stones & 88 & $70 \%$ \\
\hline Pigment stones & 25 & $20 \%$ \\
\hline Cholesterol stone & 13 & $10 \%$ \\
\hline
\end{tabular}

Table 7: Type of stones

In the present study gallstones analysis was done in all patients. 88 patients had mixed type of stones, 13 patients had cholesterol stone and 25 patients had pigment stone.

DISCUSSION: In this study 126 cases of Cholelithiasis that were admitted in Government General Hospital, Guntur from November 2012 to October 2014 were included in the study group. Well known available literature on Cholelithiasis is reviewed. In this study the results of our study are compared with those of well- known authors. After a detailed history, clinical investigations and available treatment following observations were noted.

\section{AGE INCIDENCE:}

\begin{tabular}{|c|c|c|c|c|c|c|}
\hline \multirow{2}{*}{$\begin{array}{c}\text { Age group } \\
\text { (years) }\end{array}$} & \multicolumn{2}{|c|}{ Present study } & \multicolumn{2}{c|}{ Herman's series } & \multicolumn{2}{c|}{ Rushad's series } \\
\cline { 2 - 7 } & No. & $\mathbf{\%}$ & No. & \% & No. & \% \\
\hline $11-20$ & 3 & 2 & 25 & 1.6 & 0 & 0 \\
\hline $21-30$ & 18 & 14 & 92 & 5.9 & 4 & 3.33 \\
\hline $31-40$ & 26 & 21 & 226 & 14.6 & 36 & 36.30 \\
\hline $41-50$ & 39 & 31 & 325 & 21.0 & 30 & 25.0 \\
\hline $51-60$ & 31 & 25 & 473 & 30.6 & 29 & 24.16 \\
\hline$>60$ & 9 & 7 & 352 & 23.5 & 21 & 17.5 \\
\hline
\end{tabular}

Table 8: Comparison of age incidence with other studies

In this study, cases fall between 19 and 80 years. There is an increased incidence in the $5^{\text {th }}$ and $6^{\text {th }}$ decade with the maximum incidence in the $5^{\text {th }}$ decade. Similar incidence is seen in the studies of Herman et al, $^{11}$ and Rushad's series. Hanif series showed peek incidence in $5^{\text {th }}$ decade. In western studies the peak incidence is in the $5^{\text {th }}$ and decades. The rise in the peak age of incidence is due to change in the dietary factor. Similar findings are noted in the studies of Ganey et al. ${ }^{12}$ and Moreaux et al. 13 


\section{ORIGINAL ARTICLE}

\section{ULTRASOUND FINDINGS:}

\begin{tabular}{|c|c|c|c|c|}
\hline \multirow{2}{*}{ Ultrasound findings } & \multicolumn{2}{|c|}{ Present study } & \multicolumn{2}{c|}{ Alok Sharma series } \\
\cline { 2 - 5 } & No. & $\mathbf{\%}$ & No. & \% \\
\hline Stones in gallbladder & 126 & 100 & 57 & 98.3 \\
\hline Multiple stones & 101 & 80 & 42 & 73.7 \\
\hline Thickening of gallbladder & 80 & 63 & 10 & 17.2 \\
\hline Solitary stone & 25 & 20 & 15 & 26.3 \\
\hline Mass & 5 & 4 & 1 & 1.7 \\
\hline
\end{tabular}

Table 9: Comparison of ultrasound findings with other study

Ultrasound scanning was done in all patients, all the cases revealed stone in the gall bladder. Gall bladder stones were seen in 126 patients. Out of which 25 were solitary stones, 101 were multiple, thickening of gall bladder was seen in 80 patients, mass detected in 5 patients. Many of the features in my study were similar to studies of Major Alok Sharma et al.14 Except that of thickening of the gallbladder.

Type of Operation: In the present study 40 patients underwent open cholecystectomy and 86 patients underwent Lap cholecystectomy. The conversion rate from lap to open cholecystectomy was $10 \%$. Which was more when compared with the studies of Scott et al $(4.3 \%)^{15}$.

The most common incision used in open cholecystectomy was Rt. Sub costal Incision, which was used in 30 patients, 2 patients were operated through Rt. Para median incision and 8 patients by Rt transverse incision. In 35 cases, duct first method was done and in 5 patients, fundus first method was done. The reason for fundus first method was dense adhesion. The duct first method was the method of choice. Intra operatively in 5 cases gallbladder mass was found due to perforation and presence of omentum over the gallbladder.

\section{OPERATING ROOM TIME:}

\begin{tabular}{|c|c|c|c|}
\hline Type of operation & Operating room time & Barkun et al. & Trondsen et al. \\
\hline Laproscopic cholecystectomy & $55 \mathrm{~min}$ & $73 \mathrm{~min}$ & $50 \mathrm{~min}$ \\
\hline Open cholecystectomy & $110 \mathrm{~min}$ & $86 \mathrm{~min}$ & $100 \mathrm{~min}$ \\
\hline \multicolumn{2}{|c|}{ Table 10: Comparison of operating room time with other studies } \\
\hline
\end{tabular}

The operative room time for laparoscopic cholecystectomy was ranged from 45 min to 100 min. with mean time of $55 \mathrm{~min}$ and open cholecystectomy was ranged from $100 \mathrm{~min}$ to $130 \mathrm{~min}$. with approximate average time being $110 \mathrm{~min}$. Which were similar to study of Trondsen et al ${ }^{16} .50 \mathrm{~min}$ for laparoscopic cholecystectomy and $100 \mathrm{~min}$ for open cholecystectomy. 


\section{ORIGINAL ARTICLE}

\section{DURATION OF HOSPITAL STAY:}

\begin{tabular}{|c|c|c|c|}
\hline \multirow{2}{*}{ Operation } & \multicolumn{3}{|c|}{ Length of stay (days) } \\
\hline & Present study & Barkun et al. & Trondsen et al. \\
\hline Open cholecystectomy & 8 & 4 & 4 \\
\hline Lap cholecystectomy & 3 & 3 & 3 \\
\hline
\end{tabular}

Duration of hospital stay for open cholecystectomy was more in my study compared to the studies of Trondsen et al ${ }^{16}$ and Barkun et al. ${ }^{17}$

\section{Types of stones:}

\begin{tabular}{|c|c|c|c|c|}
\hline \multirow{2}{*}{ Type of Stone } & \multicolumn{2}{|c|}{ Present study } & \multicolumn{2}{c|}{ Mathur SN et al. } \\
\cline { 2 - 5 } & No. & $\mathbf{\%}$ & No. & $\mathbf{\%}$ \\
\hline Mixed stones & 88 & 70 & 21 & 84 \\
\hline Pigment stones & 25 & 20 & 1 & 4 \\
\hline Cholesterol stone & 13 & 10 & 3 & 12 \\
\hline
\end{tabular}

Table 12: Comparison of incidence of type of stones with other studies

In the present study $70 \%$ had mixed stones and $10 \%$ had cholesterol stone. $20 \%$ had pigment stone. When compared with the studies of Mathur SN et al increased incidence of pigment stones were observed.

Postoperative Complication: In the present study wound infection was the most common complication, which was $9 \%$. The wound infection rate in the study of Saxena et al. was 6.3\%. One patient had bile leakage through the drain tube, the patient was managed conservatively and the patient improved. In this case drain was removed on the $7^{\text {th }}$ day.

\section{CONCLUSION:}

1. The incidence of gallstones was the highest in the $5^{\text {th }}$ and $6^{\text {th }}$ decades of the life with maximum incidence in the $5^{\text {th }}$ decade. Gallstones disease was more common in females.

2. The commonest symptom was pain abdomen and the commonest sign was tenderness in the right hypochondrium. Ultrasonography was the investigation of the choice. It showed multiple gallstones and thickening of the gallbladder in the majority of cases.

3. The conversion rate from laparoscopic cholecystectomy to open cholecystectomy was $10 \%$. Subcostal incision was the most common incision used for open cholecystectomy and next being the right transverse incision.

4. Wound infection was the most common complication.

5. Laparoscopic cholecystectomy reduced the duration of stay in the hospital, pain and disability as compared to open cholecystectomy.

6. The commonest type of the stone was mixed stone. 


\section{ORIGINAL ARTICLE}

\section{BIBLIOGRAPHY:}

1. Tandon R. Diseases of Gall Bladder and Biliary Tract. In: API Textbook of Medicine, Shah SN, ed. 9th ed. Mumbai: API Publications; 2012 Apr. p.911.

2. Park K. Man and medicine towards health for all. In: Park's Text book of preventive and social medicine. 17thed. New Delhi: Banarasi Das Publications; 2002 Nov. p.1-10.

3. Karan JA, Rose GJ. Cholelithiasis and cholecystectomy. In: Maingot's abdominal operations, Zynnel MJ, Schwartz SI, Ellis H, eds. 10th ed. New York: McGraw-Hill Publications; 2001. p.171738.

4. Jensen KH, Jorgensen T. Incidence of gallstones in a Danish population. Gastroenterology 1991; 100: 790-4.

5. Cuschieri A. Disorder of the biliary tract. In: Textbook of surgery. $4^{\text {th }}$ ed. Philadelphia: Arnold Publication;2002. p.375-453.

6. Blumgart LH. Gallstones and gallbladder. In: Text book of Surgery of liver and biliary tract. New York: Harcourt Publishers;2007. p.617-791.

7. McSherry CK. Cholecystectomy: The Gold Standard. Am J Surj 1989; 158: 174-8.

8. Morgenstern L, Wong L, Berci G. Twelve hundred open cholecystectomies before the laparoscopic era. A standard for comparison. Arch Surg 1992; 127: 400-3.

9. Pickleman J, Ganzalez RP. The improving results of cholecystectomy. Arch Surg 1986; 121: 930-4.

10. Johnston DE, Kaplan MM. "Pathogenesis and treatment of gallstones". The New England Journal of Medicine, 1997 Feb 11; 328(6): 412-21.

11. Hermann RE. "Biliary disease in the aging patients". New York: Masson;1983. p.227-32

12. Ganey JB, Johnson PA, Jr, Prillaman PE, McSwain GR. Cholecystectomy: clinical experience with a large series. Am J Surg 1986 Mar; 151(3): 352-7.

13. Moreaux J. Prospective study of open cholecystectomy for calculous biliary disease. Br J Surg 1994; 81: 116-9.

14. Sharma A. Towards a safer cholecystectomy - the fundus to port aapproach. Indian Journal of Surgery 1997 Jun; 141-5.

15. Scott, 1992. Scott TR, et al: Laparoscopic Cholecystectomy: a review of 12397 patients. Surg Laparosc endosc 1992; 2: 191 - 198.

16. Trodsen, 1993. Trondsen E, et al: Laparoscopic and Open Cholecystectomy: a prospective, randomized study J Surg 1993; 159: 217 - 221.

17. Barkun, 1992. Barkun JS et al: Randamized controlled trail of laparoscopic versus mini cholecystectomy. Lancet 1992; 340: 1116 - 1119. 


\section{ORIGINAL ARTICLE}

\section{AUTHORS:}

1. Katta Srinivasa Rao

2. Govindu Naik Meghavathu

3. G. Subba Rao

4. H. R. Prasad T.

\section{PARTICULARS OF CONTRIBUTORS:}

1. Associate Professor, Department of Surgery, Guntur Medical College, Guntur.

2. Assistant Professor, Department of Surgery, Guntur Medical College, Guntur.

3. Professor \& HOD, Department of Surgery, Guntur Medical College, Guntur.

FINANCIAL OR OTHER

COMPETING INTERESTS: None
4. Senior Resident, Department of Surgery, Guntur Medical College, Guntur.

NAME ADDRESS EMAIL ID OF THE CORRESPONDING AUTHOR:

Dr. Katta Srinivasa Rao, Door No: 4-22-85/3A, 1st Lane, Balaji Nagar, Mutyala Reddy Nagar Extn., Guntur - 522007, Andhra Pradesh.

E-mail: kattasrinivas2070@yahoo.com

Date of Submission: 10/09/2015. Date of Peer Review: 11/09/2015. Date of Acceptance: 21/09/2015. Date of Publishing: 30/09/2015. 